\title{
REGULAR STALAGMITES: THE THEORY BEHIND THEIR SHAPE
}

\author{
TEORETIJA RASTI PRAVILNIH STALAGMITOV
}

\author{
Wolfgang DREYBRODT ${ }^{1,2}$ and Douchko ROMANOV ${ }^{3}$
}

\begin{abstract}
UCC 551.435.834

Wolfgang Dreybrodt \& Douchko Romanov: Regular stalagmites: The theory behind their shape

Under growth conditions constant in time stalagmites grow into an equilibrium shape, which is established, when all points of its surface are shifting by the same vertical distance $\mathrm{W}_{0}=1.2 \cdot 10^{9} \cdot \alpha\left(\mathrm{c}_{\mathrm{in}}-\mathrm{c}_{\mathrm{eq}}\right) \cdot \Delta \mathrm{t}(\mathrm{cm} /$ year $)$ during a time interval $\Delta \mathrm{t}$ (years). Thereby $\alpha\left(\mathrm{c}_{\mathrm{in}}-\mathrm{c}_{\mathrm{eq}}\right)$ is the precipitation rate in molcm ${ }^{-2} \mathrm{~s}^{-1}, \mathrm{c}_{\mathrm{eq}}$ is the calcium concentration of the supersaturated solution dripping to the apex of the stalagmite, and $\mathrm{c}_{\mathrm{eq}}$ its equilibrium concentration with respect to calcite and the $\mathrm{p}_{\mathrm{CO}_{2}}$ in the cave atmosphere.

From these ingredients a numerical model of stalagmite growth into an equilibrium shape is presented. In this model one assumes idealistically that the water dripping to the apex flows continuously down the stalagmite, spreading out radially. By simple mass balance one finds that the equilibrium radius is $\mathrm{R}_{\mathrm{eq}}=\sqrt{\mathrm{V} / \pi \alpha \tau}$, where $\mathrm{V}=0.1 \mathrm{~cm}^{3}$ is the volume of a drop and $\tau$ the drip interval. Furthermore numerical modeling reproduces the vertical shifting of the stalagmite's equilibrium shape. Finally an interesting similarity rule is found. If one scales two stalagmites of differing $R_{\mathrm{eq}}$ to the same size and chooses their growth axes as common axis and their apexes as common origin, both show identical shapes. In other words regular stalagmites are similar geometrically. This similarity rule is verified by digitizing the shapes of various natural stalagmites with diameters between $5 \mathrm{~cm}$ and $20 \mathrm{~m}$. Within small natural variations, the rescaled shapes are identical and close to the shape of the numerical model.
\end{abstract}

Keywords: stalagmites, morphology, growth rates, scaling law

\section{Izvleček}

UDK 551.435.834

Wolfgang Dreybrodt \& Douchko Romanov: Teorija rasti pravilnih stalagmitov

$\mathrm{V}$ stacionarnih pogojih rasti stalagmiti zrastejo $\mathrm{v}$ ravnotežno obliko. Todosežejo, ko se vse točke na površini v določenem časovnem intervalu $\Delta t$ premaknejo za enako vertikalno razdaljo $\mathrm{W}_{0}=1.2 \cdot 10^{9} \cdot \alpha\left(\mathrm{c}_{\text {in }}-\mathrm{c}_{\text {eq }}\right) \cdot \Delta \mathrm{t}(\mathrm{cm} /$ year $)$, pri čemer je $\alpha\left(\mathrm{c}_{\text {in }}-\mathrm{c}_{\text {eq }}\right)$ hitrost odlaganja sige $\mathrm{v}$ molcm ${ }^{-2} \mathrm{~s}^{-1}, \mathrm{c}_{\text {in }}$ je koncentracija kalcija $\mathrm{v}$ raztopini, ki kaplja na teme kapnika, $\mathrm{c}_{\mathrm{eq}}$ ravnotežna koncentracija kalcija glede na kalcit, $\mathrm{p}_{\mathrm{CO}_{2}}$ pa je delni tlak ogljikovega dioksida $\mathrm{v}$ jamski atmosferi. Iz teh sestavin je narejen model razvoja stalagmita $\mathrm{v}$ ravnotežno obliko. $\mathrm{V}$ modelu predpostavimo, da voda odteka iz temena stalagmita enakomerno v radialni smeri. Iz ohranitve mase dobimo ravnotežni radij stalagmita $\mathrm{R}_{\text {eq }}=\sqrt{\mathrm{V} / \pi \alpha \tau}$, pri čemer je $\mathrm{V}=0.1 \mathrm{~cm}^{3}$ volumen vodnih kapljic in $\tau$ interval kapanja. Numerični model napove vertikalno premikanje ravnotežne oblike. $Z$ ustrezno transformacijo koordinat se nazorno izkaže, da so pravilni stalagmiti geometrijsko identični. To v članku prikažemo na izbranih primerih naravnih stalagmitov premerov med $5 \mathrm{~cm}$ in $20 \mathrm{~m}$. V okviru majnih odstopanj so umerjene oblike stalagmitov identične $\mathrm{z}$ napovedi numeričnega modela.

Ključne besede: stalagmit, morfologija, hitrost rasti, skalna invarianca.

\footnotetext{
${ }^{1}$ Karst Processes Research Group, Institute of Experimental Physics, University of Bremen, 28359 Bremen, Germany

${ }^{2}$ Karst Research Institute ZRC SAZU, Titov trg 2 SI-6230 Postojna

3 Institute of Geological Sciences, FU Berlin, Malteserstr. 74-100, Building D, 12249 Berlin
}

Received/Prejeto: 21.5.2008 


\section{INTRODUCTION}

Stalagmites are ubiquitous in many caves. They grow in a variety of shapes and sizes. Their diameters range from a few centimetres up to several meters. Fig. 1 shows a transect of a small regular stalagmite with a diameter of $4.5 \mathrm{~cm}$ (Soubies et al. 2005). The largest stalagmite in the world is reported from Cueva San Martin Infierno in Cuba. This giant stalagmite exhibits a height of about $70 \mathrm{~m}$ and $20 \mathrm{~m}$ diameter. The photo of this speleothem http://www.goodearthgraphics.com/virtcave/largest.htm is shown in Fig. 2. Both samples, although extremely different in size at a first glance look quite similar. Both shapes can be crudely described as almost regular cylinders with a half sphere at their top. Such regular stalagmites sometimes are called candle stalagmites.

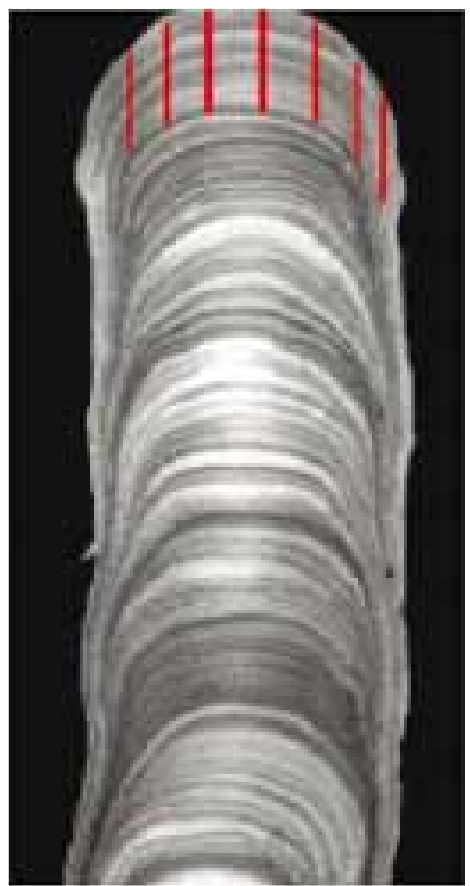

Fig. 1: Transect of a small regular stalagmite (Soubies et al. 2005) with a diameter of $4.5 \mathrm{~cm}$. The laminations show growth surfaces. The red lines show the distance between various points of two distinct growth surfaces. They are all of the same length.

Franke (1965) was the first who recognized the principle of their growth. He proposed the following mechanism assuming growth conditions constant in time. A drop of solution, supersaturated with respect to calcite falling to the ground spreads out radially when it impinges at the surface. Precipitation rates are maximal at the center and decrease with distance outwards. This way a thin layer of precipitated calcite is created. It has a lenticular shape, thick at the center and thinning out at the edges. The next layer is build in the same way on the top of the previous one and a vertical candle like shaped stalagmite grows upwards. After a height of about its diameter its shape on the

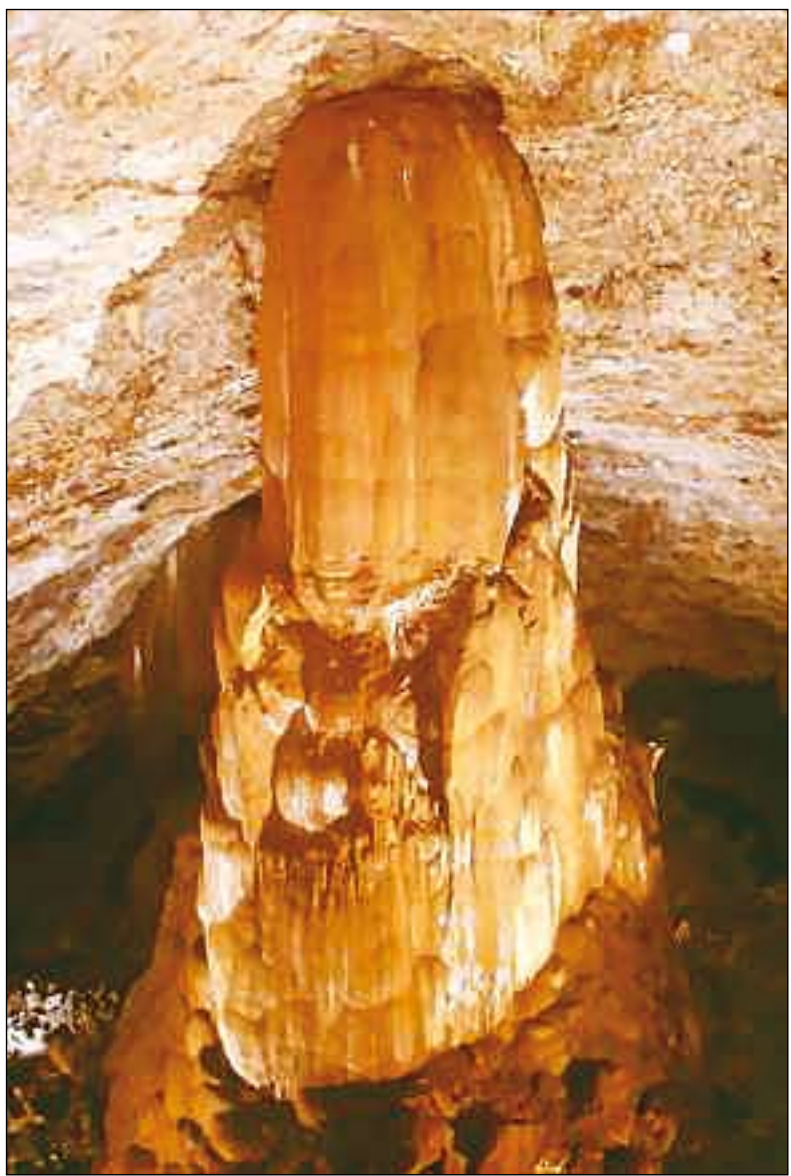

Fig. 2: The world's largest stalagmite in Cueva San Infierno, Cuba. Its height is $70 \mathrm{~m}$, its diameter $20 \mathrm{~m}$.

top becomes stable and also the diameter of the stalagmite does not change anymore. In other words the growth rates in the vertical direction are constant everywhere and the shape of the stalagmite is shifted vertically in its growth direction. This is depicted in Fig. 3. Franke suggested this principle from observation on the growth layers of transected stalagmites, such ones as shown in Fig. 1. Dreybrodt $(1988,1999)$ and Romanov et al. (2008a) derived this growth principle from three simple generally valid assumptions by use of numerical modelling, but also by strict mathematical proof. These are:

1) The point of drop impact and the drip interval are constant in time. This must be true also for temperature.

2) Growth by deposition of calcite is directed normal to the actual surface of the stalagmite. 


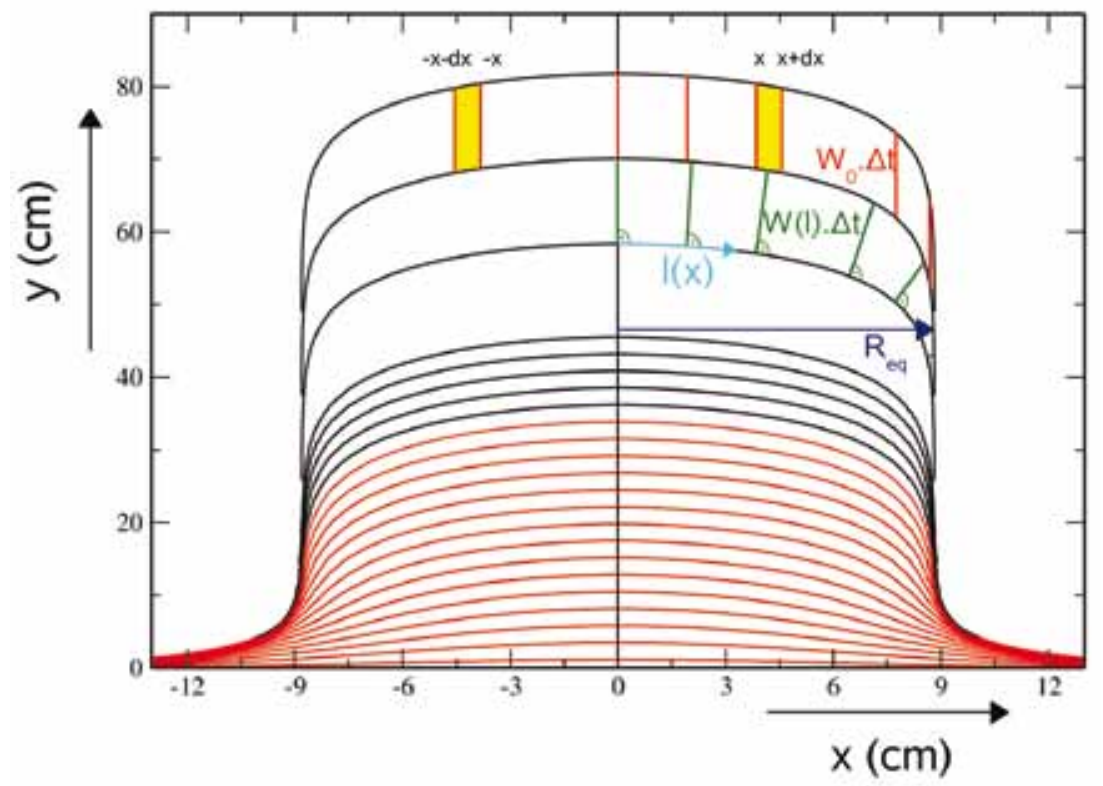

Fig. 3: Principle of stalagmite growth: The green lines depict the growth perpendicular to a growing surface during the time span $\Delta t$. They decrease with distance $\ell$ along the growing surface. The red curves show the shapes of the stalagmite when it starts to grow from a plane surface. Finally an equilibrium shape with radius $R_{e q}$ is attained (black curves). The vertical distance between to growth surfaces is shown by the red arrows with length $W_{0} \cdot \Delta t$, they are all of equal length. See also Fig. 1. The volume between the two utmost layers is composed of rings with radius $x$, width $\Delta x$ and height $W_{0} \cdot \Delta t$. Their cross section is a parallelogram with sides $\Delta x$ and $W_{0} \cdot \Delta t$. See text.

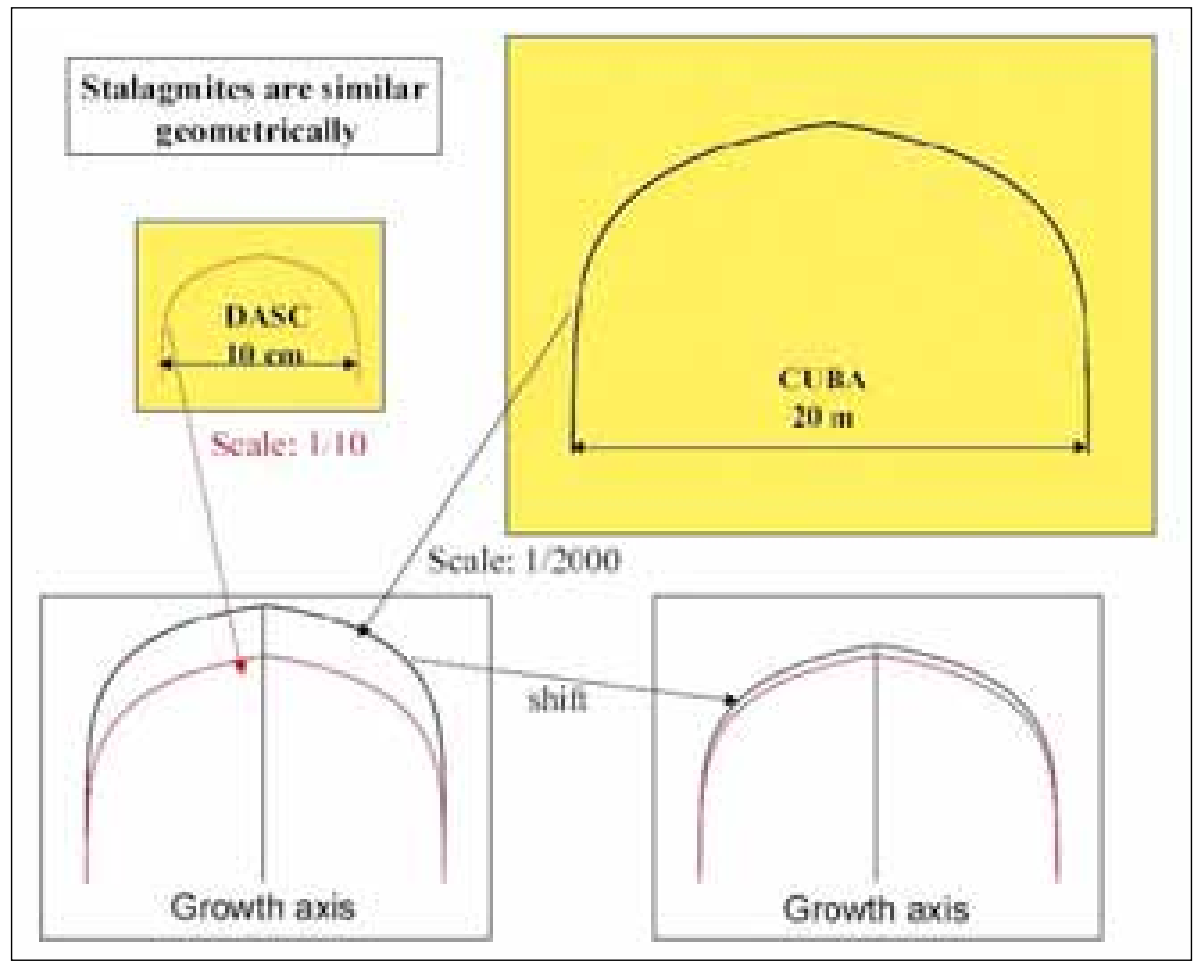

3) Growth rates $W(\ell)$ decrease monotonically with distance $\ell$ along the actual surface and become zero at some large but finite distance $\ell_{0}$.

From these assumptions one can derive also a similarity rule depicted in Fig. 4: Rescaling the shape of a regular stalagmite into dimensionless coordinates $\tilde{\mathrm{x}}=\mathrm{x} / \mathrm{R}_{\mathrm{eq}}$ and $\tilde{\mathrm{y}}=\mathrm{y} / \mathrm{R}_{\mathrm{eq}}$, choosing their growth axes as common axis, and their apexes as origin $\tilde{\mathrm{x}}=0, \tilde{\mathrm{y}}=0$ gives identical shapes, independent of the diameter $R_{\text {eq }}$ of the sample. (Romanov et al., 2008a)

In this paper we will first discuss the basic features of stalagmite growth to understand this similarity rule. In the second step we use rescaling of real regular stalagmites from diameters in the range of several centimeters up to about $20 \mathrm{~m}$ to show its validity.

Fig. 4: Schematical representation of the geometrical similarity of stalagmites: A small stalagmite with $10 \mathrm{~cm}$ diameter is scaled by a factor of 1/10. A second one of $2000 \mathrm{~cm}$ diameter is scaled by a factor of 1/2000. In the new common coordinate system they are plotted with common growth axis (a). Then the red line is shifted vertically until it merges with the black line (b). 


\section{BASIC PRINCIPLES OF STALAGMITE GROWTH}

The most important principle stated already, can be formulated as follows: Under constant growth conditions in time the top of a stalagmite attains an equilibrium shape, which during further growth is shifted up vertically. The part of the stalagmite below is a vertical cylinder with constant equilibrium radius $R_{\text {eq }}$. This is illustrated in Fig. 3. This principle has been proven by Dreybrodt (1988) and Romanov et al. (2008a) as already mentioned in the introduction. We will not repeat this proof here, but we will derive some important consequences from it.

Fig. 3 shows two growth surfaces of a stalagmite in equilibrium, which are separated by some distance $\mathrm{W}_{0} \cdot \Delta \mathrm{t}(\mathrm{cm} /$ year $)$ is the growth rate at the apex and $\Delta \mathrm{t}$ (year) the time distance when the two layers originated. The total volume $\mathrm{V}$ between these two layers is composed of circular rings with radius $\mathrm{x}$ and width $\Delta \mathrm{x}$, all with equal height $\mathrm{W}_{0} \cdot \Delta \mathrm{t}$. Summing over all of them yields

$$
\mathrm{V}=\mathrm{W}_{0} \cdot \Delta \mathrm{t} \int_{0}^{\mathrm{R}_{\mathrm{eq}}} 2 \pi \mathrm{xdx}=\mathrm{W}_{0} \pi \mathrm{R}_{\mathrm{eq}}^{2} \cdot \Delta \mathrm{t}
$$

$\mathrm{W}_{0}$ is the growth rate at the apex in $\mathrm{cm} /$ year.

Precipitation of calcite from thin films of supersaturated solutions, as they rest on stalagmites has been investigated theoretically and experimentally by Buhmann and Dreybrodt (1985) and Dreybrodt et al. (1996). These findings have been verified by measuring precipitation rates on stalagmites in relation to the chemical composition of the drip water (Baker and Smart, 1995, Baker et al., 1998, Genty et al. 2001). The precipitation rates $\mathrm{R}$ are given by

$$
\mathrm{R}=\alpha\left(\mathrm{c}-\mathrm{c}_{\mathrm{eq}}\right) \mathrm{molcm} \mathrm{s}^{-2}
$$

where $\alpha[\mathrm{cm} / \mathrm{s}]$ is the rate constant, $\mathrm{c}\left[\mathrm{mol} / \mathrm{cm}^{3}\right]$ is the actual calcium concentration in the solution, and $c_{\mathrm{eq}}$ its equilibrium concentration with respect to calcite and the partial pressure $\mathrm{p}_{\mathrm{CO}_{2}}$ of $\mathrm{CO}_{2}$ in the cave atmosphere. $\alpha$ depends on temperature. Values of $\alpha$ in the range between $0^{\circ} \mathrm{C}$ and $30^{\circ} \mathrm{C}$ are reported by Baker et al. (1998). These can be fitted by the relation

$$
\alpha=\left(0.52+0.04 \cdot \mathrm{T}_{\mathrm{C}}+0.004 \cdot \mathrm{T}_{\mathrm{C}}^{2}\right) \cdot 10^{-5} \mathrm{~cm} / \mathrm{s}
$$

where $T_{c}$ is the temperature in centigrade (Romanov et al. $2008 \mathrm{~b})$. From this one gets a increase of a factor of ten with increasing temperature from $0^{\circ} \mathrm{C}\left(\alpha=5.2 \cdot 10^{-6} \mathrm{~cm} / \mathrm{s}\right)$ to $30^{\circ} \mathrm{C}\left(\alpha=5.3 \cdot 10^{-5} \mathrm{~cm} / \mathrm{s}\right)$.
To convert the precipitation rates $\mathrm{R}\left(\mathrm{mol} /\left(\mathrm{cm}^{2} \mathrm{~s}\right)\right)$ into a growth rate $\mathrm{W}$ in $\mathrm{cm} /$ year we consider the volume of calcite deposited to $1 \mathrm{~cm}^{2}$ in 1s: This is given by

$$
\mathrm{V}_{\mathrm{s}}=\mathrm{R} \cdot \frac{\mathrm{M}}{\rho}=\mathrm{R} \cdot \frac{100}{2.7}=37.07 \cdot \mathrm{R}
$$

$\mathrm{M}$ is the molecular weight of $\mathrm{CaCO}_{3}, \mathrm{M}=100 \mathrm{~g} / \mathrm{mol}$ and $\rho=2.7 \frac{\mathrm{g}}{\mathrm{cm}^{3}}$ the specific weight of calcite. To convert this into growth of $\mathrm{cm}$ per year one has to multiply by the number $\mathrm{N}_{\mathrm{S}}$ of seconds in one year and finds $1 \mathrm{~mol} \mathrm{~cm}^{-2} \mathrm{~s}^{-1}$ $=1.168 \cdot 10^{9} \mathrm{~cm} /$ year.

Therefore

$$
\mathrm{W}=\mathrm{R} \cdot \frac{\mathrm{M}}{\rho} \cdot \mathrm{N}_{\mathrm{S}}=1.168 \cdot 10^{9} \alpha\left(\mathrm{c}-\mathrm{c}_{\mathrm{eq}}\right) \mathrm{cm} / \text { year }
$$

Now the volume $V_{d}$ deposited to the stalagmite in 1 year $(\Delta t=1)$ must be equal to the volume $V_{L}$ of the amount of calcite lost during this time from the water, which enters with concentration cin at the apex and leaves the stalagmite with equilibrium concentration $c_{e q}$.

$\mathrm{V}_{\mathrm{L}}=\frac{\mathrm{V}_{\text {drop }}}{\tau} \cdot\left(\mathrm{c}_{\text {in }}-\mathrm{c}_{\text {eq }}\right) \cdot \frac{\mathrm{M}}{\rho} \cdot \mathrm{N}_{\mathrm{s}}=\frac{\mathrm{V}_{\text {drop }}}{\tau} \cdot\left(\mathrm{c}_{\text {in }}-\mathrm{c}_{\text {eq }}\right) \cdot 1.168 \cdot 10^{9}$

$$
\mathrm{V}_{\mathrm{d}}=\mathrm{W}_{0} \pi \mathrm{R}_{\text {eq }}^{2}=1.168 \cdot 10^{9} \alpha \cdot\left(\mathrm{c}_{\mathrm{in}}-\mathrm{c}_{\mathrm{eq}}\right) \cdot \pi \mathrm{R}_{\mathrm{eq}}^{2}
$$

$\mathrm{V}_{\text {drop }}$ is the volume of the drop and $\tau$ the drip interval.

Therefore we find by equating $\mathrm{V}_{\mathrm{L}}=\mathrm{V}_{\mathrm{d}}$

$$
\mathrm{R}_{\mathrm{eq}}=\sqrt{\frac{\mathrm{V}_{\mathrm{drop}}}{\pi \alpha \tau}}
$$

This result relates in a simple way the equilibrium radius to the kinetic constant $\alpha$ and the drip interval $\tau$. Note that the radius does not depend on the initial supersaturation $\left(\mathrm{c}_{\mathrm{in}}-\mathrm{c}_{\mathrm{eq}}\right)$.

As an example one finds with $\alpha=1.3 \cdot 10^{-5} \mathrm{~cm} / \mathrm{s}$, corresponding to a temperature of $10^{\circ} \mathrm{C}$, a drop volume $\mathrm{V}_{\text {drop }}=0.1 \mathrm{~cm}^{3}$, and $\tau=30 \mathrm{~s}$ the equilibrium radius $\mathrm{R}_{\mathrm{eq}}=9 \mathrm{~cm}$, a very realistic number.

This equation also tells us that changes in drip interval $\tau$ and in kinetic constant $\alpha$ cause changes of the equilibrium radius and therefore also changes to the shape of the stalagmite. Increase in the drip interval $\tau$ or in $\alpha$ 
result in smaller diameters and cone like stalagmites can result. On the other hand decreasing $\tau$ or $\alpha$ lead to an increase of $R_{\mathrm{eq}}$ and club-like shapes arise. This has been shown by numerical simulation first by Dreybrodt (1988, 1999). Kaufmann (2002) and Kaufmann and Dreybrodt (2003) have taken climatic data from ice cores and tried to find out, how these were imprinted into the shape of stalagmites. They showed that analyzing the shapes of irregularly grown stalagmites could give some additional information to the interpretation of climate proxies from oxygen and carbon isotopes.

\section{A MODEL OF THE EQUILIBRIUM SHAPE AND THE SCALING RULE}

In our approach we assume that the water supplied to the apex spreads out to a water film, which expands radially flowing down the stalagmite in laminar flow. This way the stalagmite is covered by a water film of thickness $\delta$ with radial symmetry as shown in Fig. 5.

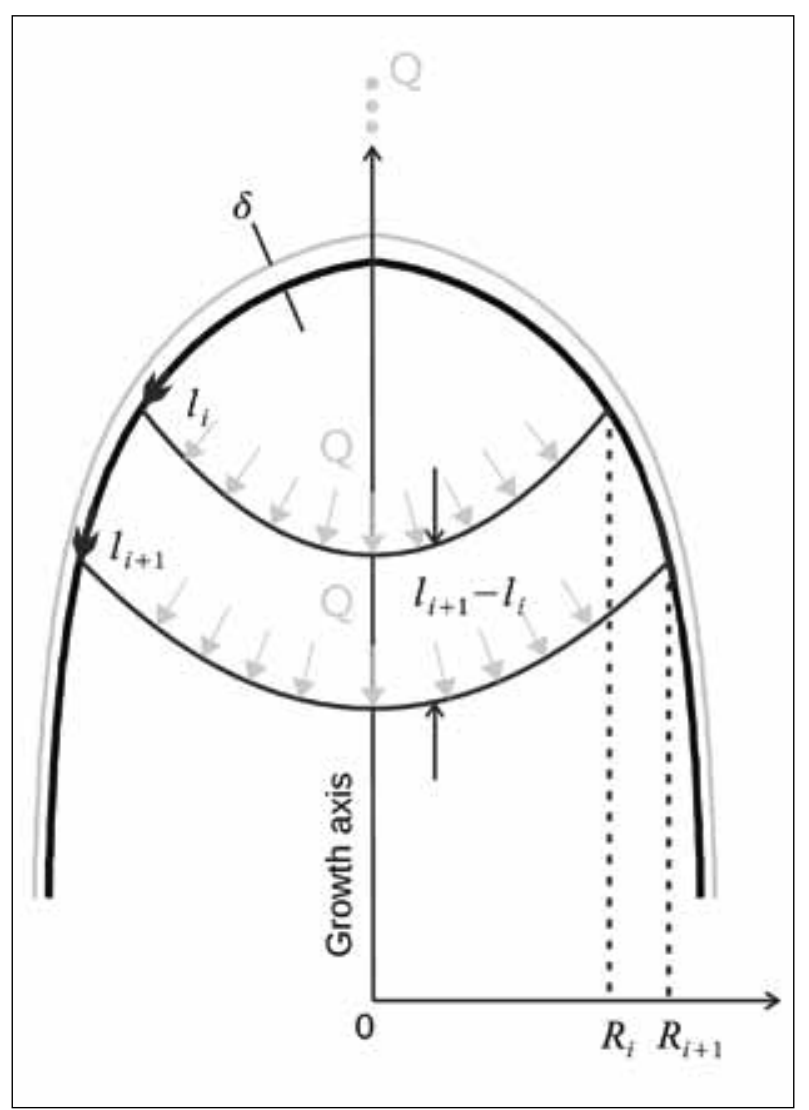

Fig. 5: A water film with thickness $\delta$ covers the stalagmite. An annulus of this film between distance $\ell_{i}$ and $\ell_{i+1}$ is shown. The water supply $Q$ flows radially from the apex. At distance $\ell_{i}$ along the growth surface the water enters into the annulus with concentration $c_{i}$ and leaves it at distance $\ell_{i+1}$ with concentration $c_{i+1}$.

We now consider an annulus between the points $\mathrm{i}$ and $i+1$ at the surface with radial distance $R_{i}$ and $R_{i+1}$ re- spectively. The distance between these two points along the surface is $1_{i+1}-l_{i}=\Delta l_{i}$.

Mass balance requires that the amount of calcite deposited to the area of the annulus between points $i$ and $\mathrm{i}+1$ must be equal to the loss of $\mathrm{CaCO}_{3}$ in the solution when passing over the annulus.

The mass of calcite lost per second from the solution covering the surface of the annulus is

$$
\mathrm{M}_{\mathrm{s}}=\mathrm{Q}\left(\mathrm{c}_{\mathrm{i}}-\mathrm{c}_{\mathrm{i}+1}\right)
$$

because the total flow $Q=V_{\text {drop }} / \tau$ enters the annulus at $R_{i}$ with concentration $c_{i}$ and leaves it at $R_{i+1}$ with concentration $c_{i+1} \cdot M_{s}$ must be equal to the mass $M_{p}$ of calcite precipitated per second to the surface $S_{a}=2 \pi \cdot \Delta l_{i} \cdot R_{i}$ of the annulus. Note that $M_{S}$ and $M_{p}$ in this context are in $\mathrm{mol} / \mathrm{s}$.

$$
\mathrm{M}_{\mathrm{p}}=2 \pi \cdot \Delta \mathrm{l}_{\mathrm{i}} \cdot \mathrm{R}_{\mathrm{i}} \cdot \alpha \cdot\left(\mathrm{c}_{\mathrm{i}}-\mathrm{c}_{\mathrm{eq}}\right)
$$

Equating $\mathrm{M}_{\mathrm{p}}=\mathrm{M}_{\mathrm{s}}$ one obtains

$$
c_{i+1}=c_{i}-2 \pi \cdot \alpha \cdot\left(c_{i}-c_{e q}\right) \cdot R_{i} \frac{\Delta l_{i}}{Q}
$$

From this the deposition rates $\mathrm{W}_{\mathrm{i}+1}$ can be calculated by subtracting $c_{\text {eq }}$ from both sides of the equation and then multiplying both sides by $\alpha$

$$
\mathrm{W}_{\mathrm{i}+1}=\mathrm{W}_{\mathrm{i}}\left(1-2 \pi \cdot \alpha \cdot \mathrm{R}_{\mathrm{i}} \frac{\Delta \mathrm{l}_{\mathrm{i}}}{\mathrm{Q}}\right)
$$

Remembering that $\mathrm{R}_{\mathrm{eq}}=\sqrt{\frac{\mathrm{V}_{\mathrm{drop}}}{\pi \alpha \tau}}=\sqrt{\frac{\mathrm{Q}}{\alpha \pi}}$ eqn. 11 can be rewritten as

$$
\mathrm{W}_{\mathrm{i}+1}=\mathrm{W}_{\mathrm{i}} \cdot\left(1-2 \cdot \frac{\mathrm{R}_{\mathrm{i}} \Delta \mathrm{l}_{\mathrm{i}}}{\mathrm{R}_{\mathrm{eq}}^{2}}\right)
$$

This recursive equation shows growth rates declining with distance $\mathrm{l}_{\mathrm{i}}$. Rewriting eqn.11 as 
$\frac{\mathrm{W}_{\mathrm{i}+1}-\mathrm{W}_{\mathrm{i}}}{\mathrm{W}_{\mathrm{i}}}=\frac{\mathrm{W}\left(\mathrm{l}_{\mathrm{i}+1}\right)-\mathrm{W}\left(\mathrm{l}_{\mathrm{i}}\right)}{\mathrm{W}\left(\mathrm{l}_{\mathrm{i}}\right)}=2 \cdot \frac{\mathrm{R}_{\mathrm{i}} \Delta \mathrm{l}_{\mathrm{i}}}{\mathrm{R}_{\mathrm{eq}}^{2}}$

In the limit of very small $\Delta \mathrm{l}_{\mathrm{i}}=\mathrm{dl}$ we obtain

$\frac{\mathrm{dW}(\mathrm{l})}{\mathrm{W}(\mathrm{l})}=\frac{2 \mathrm{Rdl}}{\mathrm{R}_{\mathrm{eq}}^{2}} \geq \frac{2 \mathrm{ldl}}{\mathrm{R}_{\mathrm{eq}}^{2}}$

because $\mathrm{l}(\mathrm{R}) \geq \mathrm{R}$.

Integrating eqn. 14 yields

$$
\mathrm{W}(\mathrm{l}) \leq \mathrm{W}_{0} \cdot \exp \left(-\frac{1^{2}}{\mathrm{R}_{\text {eq }}^{2}}\right)
$$

Since the Gauss-function is monotonically deceasing with distance 1 this must be true also for $\mathrm{W}(\mathrm{l})$.

Equation 11, which contains only defined parameters and the somewhat idealistic assumption of continuous flow spreading out radially can be used for numerical modelling. This has been performed as FLOW-model by Romanov et al. (2008). They employed the following procedure. The actual surface of the stalagmite at time $t$ is approximated by the polygon $P_{1}$ to $P_{n}^{\prime}$ where $P_{1}$ is the point of drip impact. The surface at later time $t+\Delta t$ is obtained by drawing vertical lines with lengths $\mathrm{W}\left(\mathrm{l}_{\mathrm{i}}\right) \cdot \Delta \mathrm{t}$ from points $i$. This way the three basic assumptions on stalagmite growth are fulfilled and the new surface is approximated by the polygon $\mathrm{P}_{1}{ }_{1}$ to $\mathrm{P}_{\mathrm{n}}{ }_{\text {as }}$ shown in Fig. 6 .

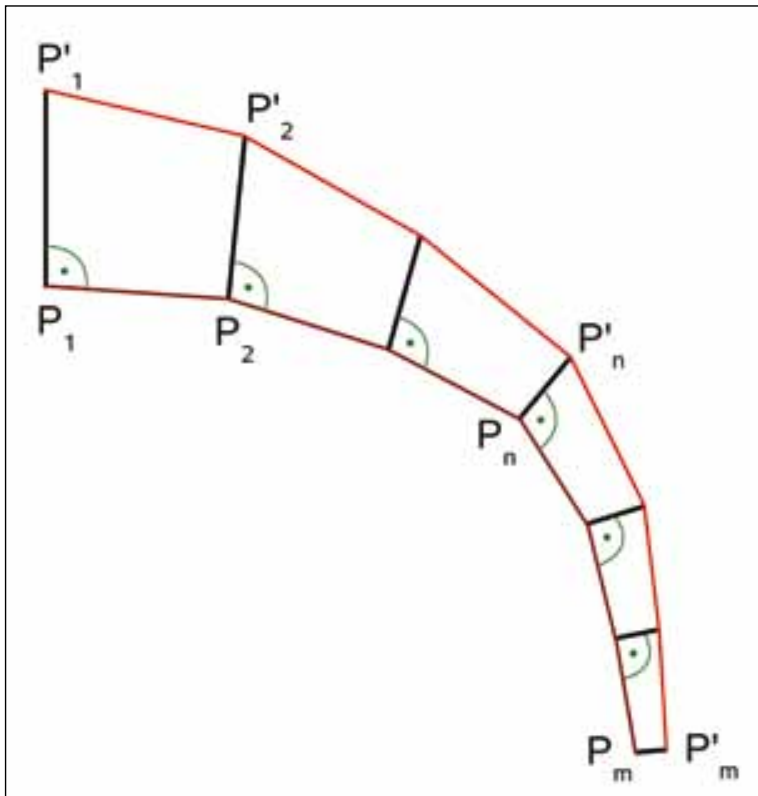

Fig. 6: Consecutive construction of a new growth surface $P_{1}^{\prime} P_{n}^{\prime}$ from an actual surface $P_{1} P_{n}$. The distances $P_{n} P_{n}^{\prime}$ depend on the lengths along the actual surface $P_{1} P_{n}$. They decrease with $n$. $P_{1}^{\text {' are }}$ the points of drip impact (see text).

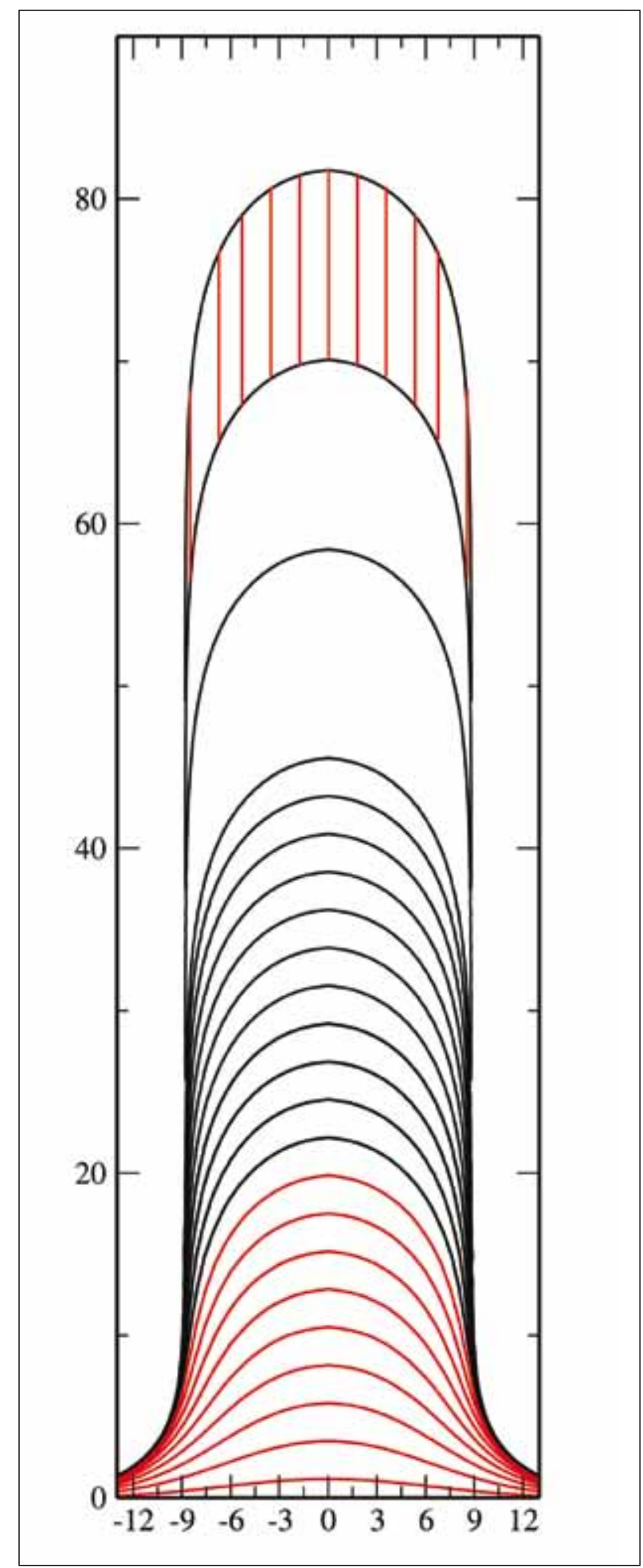

Fig. 7: Computer simulation of a stalagmite by the FLOW-model: $V_{\text {drop }}=0.1 \mathrm{~cm}^{3}, \tau=30 \mathrm{~s}, \alpha=1.3 \cdot 10^{-5} \mathrm{~cm} / \mathrm{s}\left(T=10^{\circ} \mathrm{C}\right)$. The red lines show the initial state of growth until an equilibrium shape is attained (black curves). The growth surfaces are shown every 200 years in the lower part and every 1000 years in the upper part. The vertical lines between the two utmost surfaces are all of equal length $W_{0} \cdot \Delta t . \Delta t=1000$ years 
Here we do not give technical details but we represent the results of the FLOW- model. These are shown in Fig.7. It depicts growth layers of a stalagmite growing on a plane surface. Note that the $\mathrm{x}$ and $\mathrm{y}$ axes have identical scales. Therefore the picture presents the natural undistorted shape. Clearly the shape of the stalagmite changes in its initial stage of growth (black lines) until an equilibrium shape is attained (red line) from then on this shape is maintained for further growth and the vertical distance between any two equilibrium growth layers remains constant on all points of the surface. The vertical red lines, all of equal lengths between the two upper surfaces indicate this. A further point to be noted is that the equilibrium shape is attained after a growth height close to its diameter.
The similarity rule can be obtained from eqn.12. By introducing dimensionless coordinates $\tilde{\mathrm{x}}=\mathrm{x} / \mathrm{R}_{\mathrm{eq}}$ and $\tilde{y}=\mathrm{y} / \mathrm{R}_{\mathrm{eq}}$ one finds

$$
\mathrm{W}_{\mathrm{i}+1}=\mathrm{W}_{\mathrm{i}} \cdot\left(1-2 \cdot \tilde{\mathrm{R}}_{\mathrm{i}} \cdot \Delta \tilde{\mathrm{l}}_{\mathrm{i}}\right)
$$

This, however, means that any regular stalagmite scaled by the factor $1 / R_{\text {eq }}$, into this new coordinate system must exhibit a unique shape independent on its former dimensions.

This proves the scaling rule depicted in Fig. 4: Scale the stalagmites in both coordinates by the factor $1 / R_{\mathrm{eq}}$ and chose their growth axis as y-coordinate and their apex as origin. Then all regular stalagmites have the same shape.

\section{VERIFICATION OF THE SCALING RULE ON NATURAL STALAGMITES}

To prove this by observation one has to select regular stalagmites, which show vertical walls about 1 diameter below their apex. Two extreme examples are shown in Figs. 1 and 2.
We have selected six transections of stalagmites, which are exhibited in the Deutsche Archiv für Sinterchronologie (DASC) in the Schillat-cave, located in a limestone quarry close to Hessisch-Oldendorf, Germa-
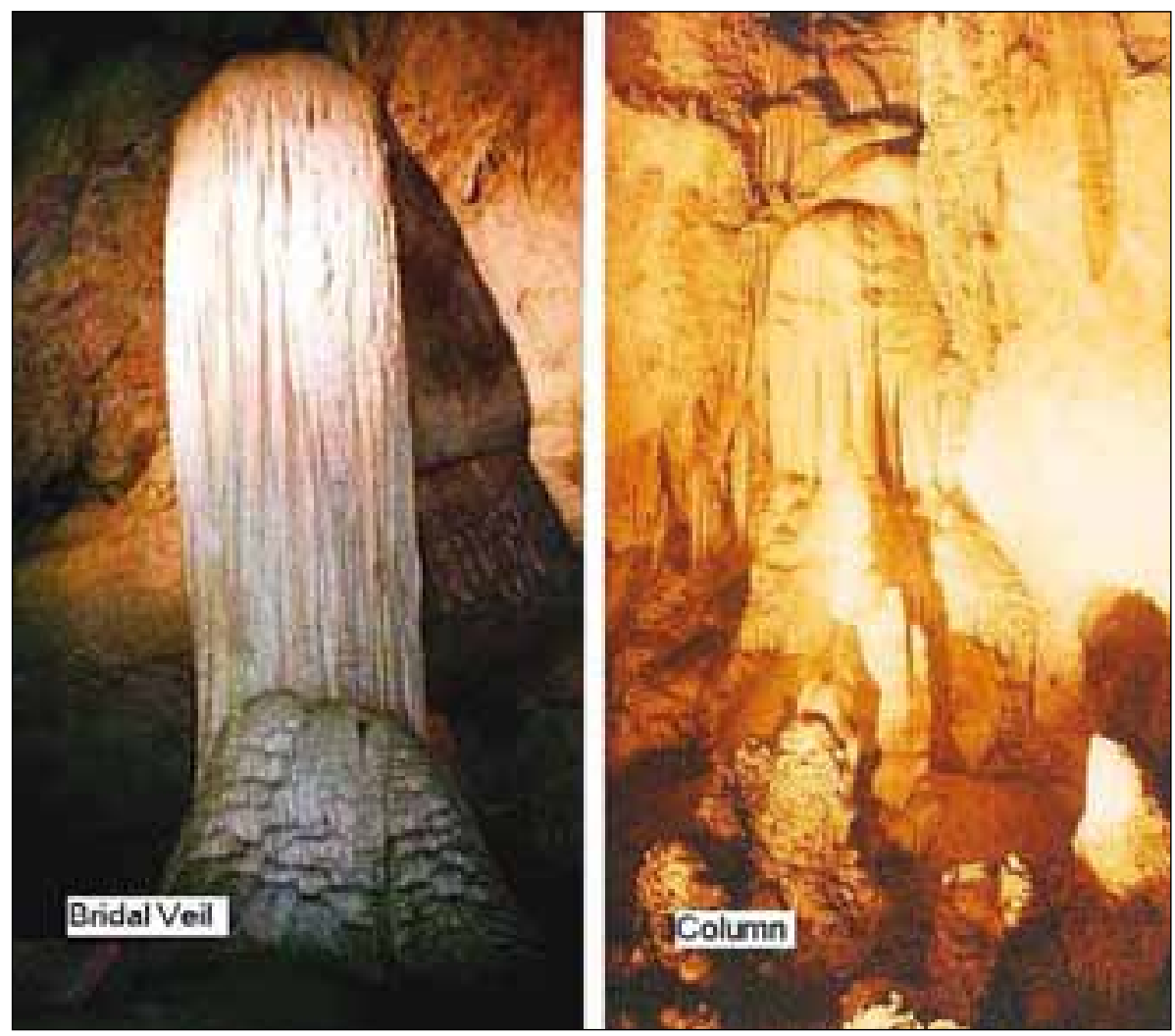

Fig. 9: Two large stalagmites: Column from Kings Palace, Carlsbad Caverns, New Mexico, USA and the Bridal Veil, Lost world Caverns, West Virginia, USA. 
a)

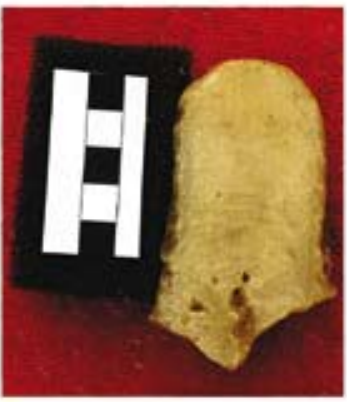

d)

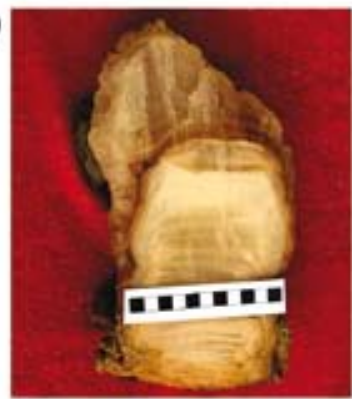

g)

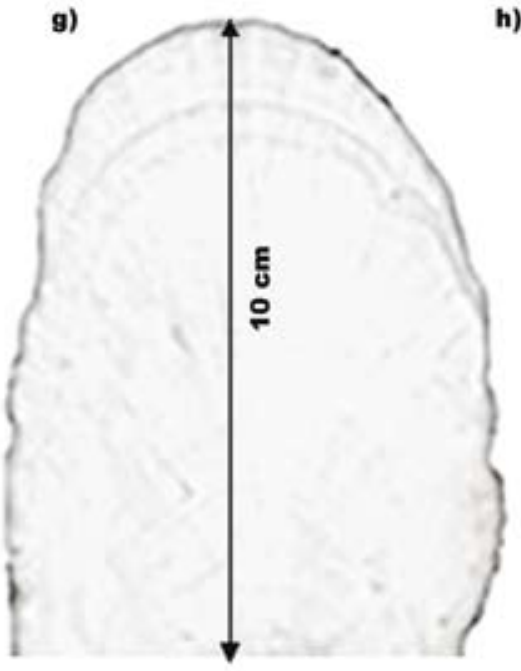

b)

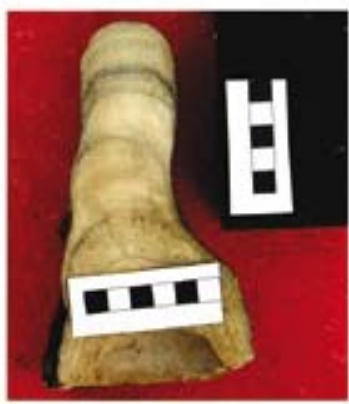

e)

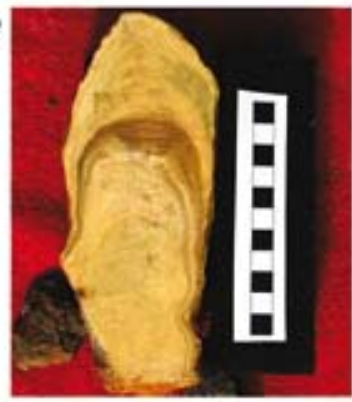

h)

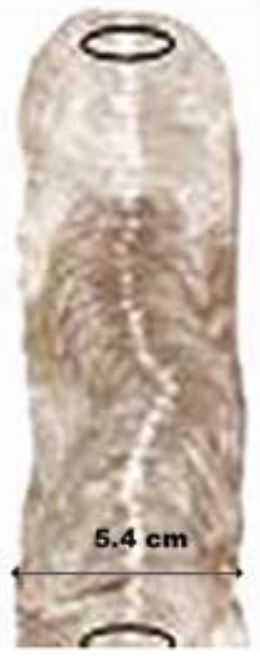

c)

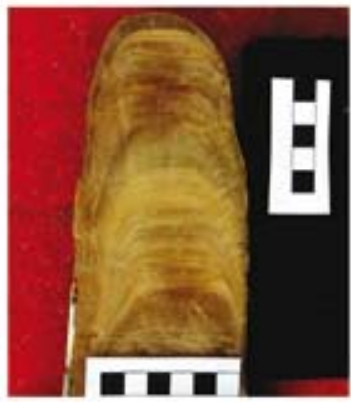

f)

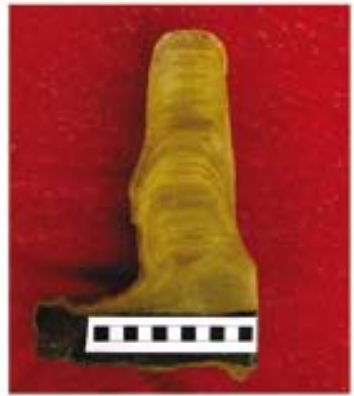

i)

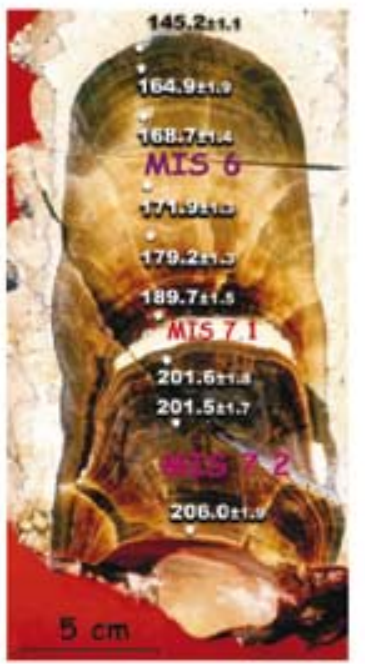

Fig. 8: Regular small stalagmites from the Deutsche Archiv for Sinterchronologie (DASC) used to test the similarity rule. Regular stalagmites taken from the literature are also shown (see text). a) dasc1, b) dasc2, c) dasc3, d) dasc4, e) dasc $9, f$ ) Frisia, $g$ ) Genty, h) Bard. The black snd white squares at the base of stalagmites are $1 \mathrm{~cm} \times 1 \mathrm{~cm}$.

ny. These stalagmites exhibit diameters between $4 \mathrm{~cm}$ to $8 \mathrm{~cm}$. They are shown in Fig. 8 .

Furthermore four stalagmites have been taken from the literature: Bard et al. (2002), Fig. 1, Frisia et al. (2006), Fig. 2, both with diameters of $10 \mathrm{~cm}$, Genty et al. (2006), Fig. 4, with a diameter of $5 \mathrm{~cm}$, and Soubies et al. (2005), Fig. 2a with $4.5 \mathrm{~cm}$ diameter. These are also shown in Fig.8. We have digitized suitable growth layers of the surface of those stalagmites and rescaled them. We have also performed a search of regular large stalagmites in the Internet and found the world largest regular stalagmite with a diameter of $20 \mathrm{~m}$ shown in Fig. 2. Other ones have been found on the from Carlsbad Caverns, New Mexico, USA, a column with $4 \mathrm{~m}$ diameter (http:// www.fingerlakesbmw.org/visual/az/cccolumn1.jpg) and finally from Lost World Caverns, West Virginia, USA, the Bridal Veil with $2 \mathrm{~m}$ diameter, (http://www.wonderfulwv.com/archives/june01/fea1.cfm). Pictures of these two stalagmites are shown in Fig. 9. 


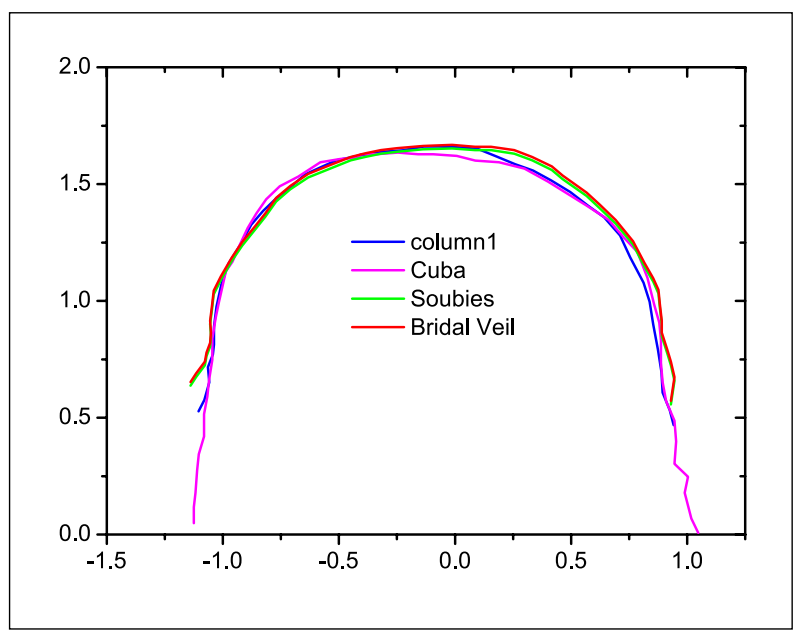

Fig. 10: Rescaled shapes of three large stalagmites and one small stalagmite. See color legend.

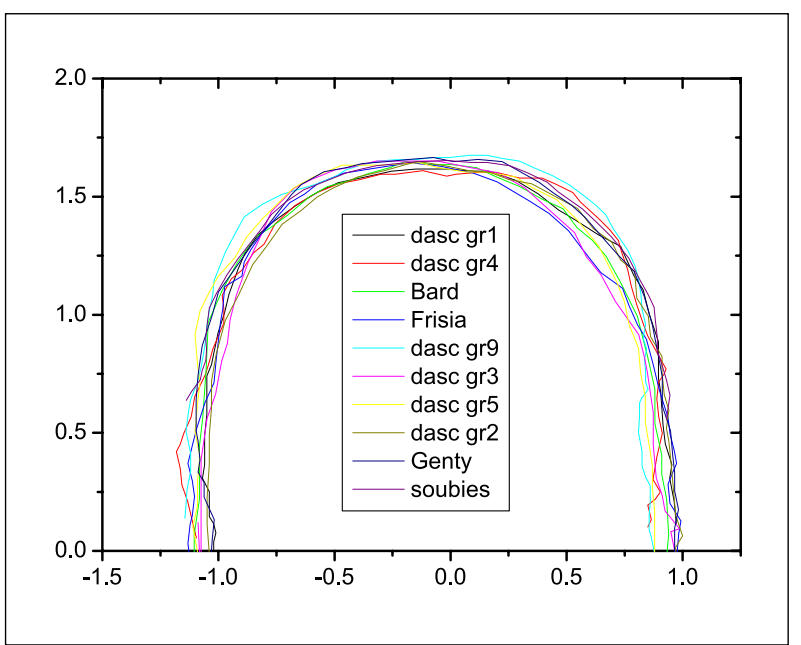

Fig. 11: Rescaled shapes of the stalagmites from Fig. 8. See color legend.

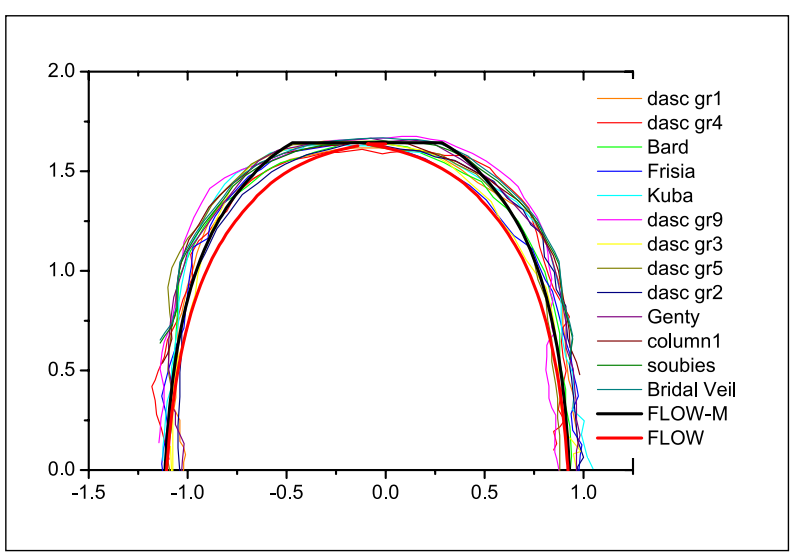

Fig. 12: Rescaled shapes of all stalagmites compared to the shape obtained from the FLOW-model and a modified FLOW-model FLOW-M.

To compare the shapes we have rescaled all stalagmites to the same radius $\widetilde{R}_{\text {eq }}=1$.

In Fig. 10 the rescaled shapes of the stalagmite from Cuba, Column, and the Bridal Veil are shown. Within some natural variation all these shapes are almost the same. We have also added the smallest stalagmite with $4.5 \mathrm{~cm}$ from the paper of Soubies et al. (2005), (see Fig. 1). Its shape fits nicely with those of the large stalagmites.

Fig.11 compares the shapes of all small stalagmites from Fig. 1 and Fig. 8, which also prove the similarity rule. Finally, in Fig. 12 we have plotted the complete selection of our samples and compare it to the theoretically obtained rescaled shape of the FLOW-model depicted in Fig. 7.

Although not perfect the theoretical shape is quite close to the natural shapes.

\section{DISCUSSION AND CONCLUSION}

We have shown that the shapes of regular stalagmites are similar from very small equilibrium diameters of several centimetres over three orders of magnitude up to $20 \mathrm{~m}$. This is a rather unexpected result because the hydrodynamic flow conditions are extremely different. Small stalagmites up to diameters of several $10 \mathrm{~cm}$ are fed by drops with drip intervals of about $10 \mathrm{~s}$ for a diameter of $30 \mathrm{~cm}$ and $200 \mathrm{~s}$ for a diameter of about $5 \mathrm{~cm}$. To obtain a diameter of $20 \mathrm{~m}$ a water supply of $40 \mathrm{~cm}^{3} / \mathrm{s}$ or 400 drops/s are necessary. Whenever a drop impinges to the surface of a stalagmite splashing will occur and the drop or the continuous flow of water will cover the central part of the stalagmite's surface by water film, which acts like a reservoir from which outward flow is supplied. In this water film due to mixing, when a new drop impinges, a constant calcium concentration will be maintained and the growth rate is constant within the radius where this water film covers the stalagmite.

To model the shape of this stalagmite requires $\mathrm{W}_{\mathrm{i}}=\mathrm{W}_{0}$ for all points $\mathrm{i}$ with $\mathrm{R}_{\mathrm{i}} \leq \mathrm{R}_{\mathrm{c}}$. For $\mathrm{R}_{\mathrm{i}}>\mathrm{R}_{\mathrm{c}}=0.33 \cdot \mathrm{R}_{\mathrm{eq}}$ the recursive equation 11 is valid. 
The comparison of the equilibrium shapes is shown in Fig. 12. The new shape (black fat line) is exactly what one obtains by cutting the upper part of the idealised stalagmite (obtained from the FLOW - model). The modified model FLOW-M comes closer to the real shapes although it is not perfect. The FLOW- model exhibits a sharper tip.
Concluding we can state that although hydrodynamics are different for small and large stalagmites, they all obey a similarity law, which indicates that the detailed growth mechanisms must be very similar. It may be a topic of future research to incorporate the hydrodynamics including surface tension of the water flowing away from the apex into further more realistic growth models.

\section{ACKNOWLEDGEMENT}

We thank Mr. Hartmut Brepohl and the team of the Schillat Cave for their kind and helpful support during our visit to take the pictures of the stalagmites.

\section{REFERENCES}

Baker, A., \& Smart, P. L., 1995: Recent flowstone growth rates: field measurements in comparison to theoretical prediction.- Chemical Geology 122, 121-128.

Baker, A., Genty, D., Dreybrodt, W., Barnes, W. L., Mockler, N. J., \& Grapes, J., 1998: Testing theoretically predicted stalagmite growth rate with recent annually laminated samples implications for past stalagmite deposition.- Geochimica et Cosmochimica Acta , 62, 393-404

Bard, E., Antonioli, F., \& Silenzi, S., 2002: Sea-level during the penultimate interglacial period based on a submerged stalagmite from Argentarola Cave (Italy).- Earth and Planetary Science Letters 196, 135146.

Buhmann, D., \& Dreybrodt, W., 1985: The kinetics of calcite dissolution and precipitation in geologically relevant situations of karst areas: 1. Open system.Chemical Geology 48, 189-1211.

Dreybrodt, W., 1988: Processes in Karst Systems - physics, chemistry, and geology. Springer. Berlin.

Dreybrodt, W., 1999: Chemical kinetics, speleothem growth and climate.- Boreas 82, 347-356.

Dreybrodt, W., Eisenlohr, L., Madry, B. \& Ringer, S., 1997: Precipitation kinetics of calcite in the system: the conversion to $\mathrm{CO}_{2}$ by the slow process $\mathrm{H}^{+}+$ $\mathrm{HCO}_{3}^{-} \rightarrow \mathrm{CO}_{2}+\mathrm{H}_{2} \mathrm{O}$ as a rate limiting step.- Geochimica et Cosmochimica Acta 60, 3897-3904.

Frisia, S., Borsato, A., Mangini, A., Spötl, C., Madonia, G., \& Sauro, U., 2006: Holocene climate variability in Sicily from a discontinuous stalagmite record and the Mesolithic to Neolithic transition.- Quaternary Research 66, 388-400.
Franke, H. W., 1965: The theory behind stalagmite shapes.- Studies in Speleology 1, 89-95.

Genty, D., Baker, A., \& Vokal, B., 2001: Intra- and interannual growth rate of modern stalagmites.- Chem. Geol., 176, 191-212. John Wiley \& Sons Ltd.

Genty, D., Blamart, D., Ghaleb, B., Plagnes, V., Caussed,C., Bakalowicz, M., Zouarif, K., Chkir, N., Hellstrom, J., Wainer, K., \& Bourges, F., 2006: Timing and dynamics of the last deglaciation from European and North African $\delta^{13} \mathrm{C}$ stalagmite profiles- comparison with Chinese and South Hemisphere stalagmites.Quaternary Science Reviews, 25, 2118-2142.

Kaufmann, G., 2003: Stalagmite growth and paleoclimate: the numerical perspective.- Earth and Planetary Science Letters., 214, 251-266.

Kaufmann, G., \& Dreybrodt, W., 2004: Stalagmite growth and paleoclimate: an inverse approach. - Earth and Planetary Science Letters, 224, 529-545.

Romanov, D., Kaufmann, G., \& Dreybrodt, W., 2008 a: Modeling stalagmite growth by first principles of chemistry and physics of calcite precipitation.Geochimica et Cosmochimica Acta , 72, 423-437.

Romanov, D., Kaufmann, G., \& Dreybrodt, W., 2008 b: $\delta^{13}$ profiles along growth layers of stalagmites: Comparing theoretical andexperimental results.Geochimica et Cosmochimica Acta,72, 438-448.

Soubies, F., Seidel, A., Mangin, A., Genty, D., Ronchail, J., Plagnes V., Hirooka, S., \& R. Santos, R., 2005: A fifty-year climatic signal in three Holocene stalagmite records from Mato Grosso-Brazil.-Quaternary International 135 (2005) 115-129. 